drance nor offer any insurmountable barrier to small, creeping ants, they yet serve to divert such visitors from the flowers, and detain them from further advance. I do not therefore hesitate to interpret all nectar-glands that are found on leaves, as a means of protection against the unwelcome, because unprofitable, visits of creeping insects."-J. J. DAvis, Racine, Wis.

One-leaved Strawberries. - The one-leaved strawberry, Fragaria monophylla, $L$., is recognized as a variety only of $P$. vesca, $L$. If my memory serves me truly, Duchesne refers to a one-leaved strawberry also. At the New York Agricultural Experiment Station we have seedlings from the Bidwell and Manchester varieties, which show plants distinctly one-leaved, other plants with petioles bearing one, two and three leaflets, axd yet other plants of the normal character.

While speaking of strawberries let me call attention to what Miss Bird, that interesting and accurate traveler, says in her "Unbeaten Tracks in Japan," page 45: "Lieut. Hawes gave us some strawberries, which have lately been introduced, and they had a good flavor; but people think they will soon lose it, as other exotic fruits have done before them. A day or two ago we had some fully ripe strawberries of a pale pea-green color, with a strong odor and flavor, not of strawberries, but of the Catawba grape."-E. Lewis Sturtevant.

\title{
EDITORIAL NOTES.
}

DR. C. C. PARRY is now residing at Davenport, Iowa.

Dr. Oswald Heer, of Zürich, Switzerland, the celebrated paleontologist, and eminent authority on fossil botany, is dead.

The Canadian Naturalist has been discontinued by the Nat. Hist. Society of Montreal, which will at once begin the publication of its transactions in a similar form.

Dr. Gray points out in the Am. Jour. Sci. for October that the spelling Speiranthes for the orehid-genus Spiranthes in Watson's "Contributions XI," is purely accidental, although occurring six times besides in the index.

IT sEEMS from the investigations of Julius Wortmann, given in the Botanische Zeitung, that radiant heat acts upon growing organs in a similar manner to the action of light, producing positive and negative thermotropism.

Prof. Lester F. WARD, of Washington, has recently collected a fine set of fossil plants in the valley of the Yellowstone, near Glendive, Montana. In the number, perfection and rarity of the specimens, it is the best ever obtained in the country.

The Brological Laboratory of Wabash College, at Crawfordsville, Ind., now nearly completed, will greatly facilitate the study of botany at that institution, and is expected to give another center for the pursuit of original investigation. The botanical portion consists of a laboratory for general and one for special work and the herbarium room. 
The British Association has granted $\$ 4,300$ for promotion of scientific investigation in biology the coming year, not a penny of which goes to botany. Of this sum $\$ 750$ is absorbed in bibliographical work in zoology. Is botany without wants or without advocates?

Prof. S. A. Forbes is studying the diseases of caterpillars at the Illinois State Laboratory of Natural History, and finds that some native species are infested with Micrococcus bombycis, the silk-worm disease, while the cabbageworm (Pierisrapce) is attacked by a still more deadly Micrococcus.

Mr. Meenan, editor of the Gardeners' Monthly, made an extended trip through Alaska during last July. He reports a climate and soil equalling that of England, in which cauliflowers and most other common garden vegetables do well. Wild fruits, such as crabapples, strawberries, raspberries, blackberries, black currants, gooseberries, huckleberries and juneberries, some sorts of a superior quality, abound.

SAPORTA and MARION, in their work on the paleontological development of the plant-kingdom, consider that the cryptogams find their highest development in the heterosporous Lepidodendra of the carboniferous period and then degenerate into the small Selaginellae and Isoetce of the present time. The main line of direct descent from the protophyta was not continued, but distanced and overpowered by gymnosperms which had already appeared in the carboniferous.

M. JEAN Dufour recently gave an account before the Société Vaudoise of a fungus, which he names Torula spongicola, found on toilet sponges in daily use. It encrusts the surface of the sponge either partially or wholly to an ultimate depth of 5 to $10 \mathrm{~mm}$., with a soft black more or less granular layer, consisting largely of the conidial spores with bacteria in zooglœa state and some organic débris. Using the sponge does not dislodge it, and soap has little or no effect upon its growth. Culture on gelatine under the direction of Dr. DeBary met with no success.

Cassino's Scientific and Literary Gossip, published at Boston, closes its first volume of twelve numbers with the issue for October 15 . The announcement for the coming year promises an increase in size to 24 pages, warranted by increased facilities for obtaining the latest news and opinions, a change of name to Science Record, being more exclusively devoted to the natural and physical sciences, and an advance of the annual subscription to one dollar. It is well printed and edited, and fully worth the price asked. Botanists will find many notes of interest in it.

Mr. W. F. Bundy gives a partial list of the the fungi of Wisconsin in the Geology of Wisconsin, Vol. I, enumerating about 300 species, of which over 80 belong to the genus Agaricus. The classification is that of Cook's Handbook, which, owing to the rapid advance of our knowledge, is really quite antiquated. It looks strange to see such extreme forms as the puff-balls and slime-moulds brought into juxtaposition, and to find Ustilago, Cystopus and Uredo, all in one 
order. We believe it would be better to omit the names of orders and families, and let the species stand in a continuous list, when found impracticable to give later and more natural classification. Three new species are described: Panus tomentosus, Boletus radicosus, and B. lateralis.

Mr. G. D. Swezey gives, in the first volume of the Geology of Wisconsin, a list of the vascular plants of the State. The author remarks in a prefatory note that he has not been able to follow the "rule of including only such species as have passed under his eye or are preserved in herbaria accessible to the botanist," and for just this reason it is of the slightest possible specific value, although it is obvious that the author has been conscientious in the compilation. If following the "strict and better rule" just referred to abridges a list so much as to present but an imperfect view of the vegetation of the State, why not indicate every unverifiable addition by a difference in type, an asterisk, or other device? This would give a residuum of real scientific value, and not materially interfere with the length or appearance of the catalogue. Mr. Swezey's list is in other respects an excellent one, full and with synonymy brought down to date. He desires corrections and additional information with a view to future publication.

The Lens, an illustrated octavo journal published in 1872--73, by the State Microscopical Society of Illinois, contains many things of permanent value to the botanist. It was discontinued at the end of the second volume, and since has been difficult to obtain. At the last meeting it was decided to offer the few copies still possessed by the society at half the original price, postage added (published at $\$ 3.00$ per volume; address the society at $263 \mathrm{Wa-}$ bash ave., Chicago, Ill.). The longer botanical articles are: Babcock's "Flora of Chicago," full and authentic; Babcock on forms of leaves in "Hepatica," with plate; Samuel Lockwood on "Cultivating wild flowers"; Thomas Meehan "On the agency of insects in obstructing evolution"; various articles by H. L. Smith on diatoms, among them his invaluable "Conspectus of the families and genera of the Diatomaceœ," and "The genus Amphora," with descriptions and illustrations of the 76 species; S. A. Briggs on Diatomacere of Lake Michigan, Huron, Rhode Island, etc.; Olney's "Algæ Rhodiaceæ," and others, besides several shorter articles.

The History of the spread of the mallow rust, Puccinia Malvacearum, Montg., a very destructive disease of the various mallows, especially of Malva sylvestris and Althoea rosea, is full of interest. The fungus is a native of Chili, and made its first appearance in Europe in Spain, in 1869. In four years it had spread along the Mediterranean coast as far east as Athens, in Greece, and northward through France and the southern portions of Germany and England. In 1874 it invaded northern Germany, in 1875 Ireland, and in 1876 Hungary. Its most northern continental point was, up to the close of last season, at Königsberg in northern Prussia, that is, if we except an accidental occurrence in Finland, in 1874, while the center of its greatest developement is along the Rhine. It has also appeared in Australia and the Cape of Good 
Hope, but not yet reported in North America. A very full account of its sprcad through Europe to 1879 , accompanied by a map and bibliography of the invasion, was given by Egon Ihne in the 18th report of the Upper Hessian Gessellschaft für Natur-und Heilkunde.

\section{CURRENT LITERATURE.}

To the fringed Gentian, by W. C. Bryant. Illuminated, 8vo. Cassino \& Co. , Boston, 1883.

This beautiful befringed brochure of a half dozen leaves of heavy card, shows the excellent treatment that has attracted favorable attention to the several large illustrated works on popular natural history issued by this firm. The drawing and coloring of the delicate flower, which is the motif to author and artist, together with the decorative setting, is good, although so much can not be said of the head of Bryant which is three times introduced.

Flore de la Suisse et ses origines, par le Dr. H. Christ.

The above work is a volume of 571 octavo pages, sumptuously gotten up, and illustrated by colored maps and full page illustrations. It is in no sense a manual or flora, but a learned and philosophical treatise, most entertaining withal, upon the phyto-geography of Switzerland, and the origin of its plants. It is a wonderful record of patient and careful work, and to the tourist who thinks as well as sees, must be of the greatest value. We hope that many copies may reach this country, where they can not fail to be appreciated.

Flora Peoriana: die Vegetation im Clima von Mittel-Illinois, von Friedrich Brendel. From "Természetrajzi Füzetek," Vol. V. Roy. 8vo, 107 pp. Budapest, 1882.

This is a painstaking and comprehensive account of the flora of Peoria, Ill., written in the German language. The first fifty pages are devoted to topography, climate and general remarks on the vegetation, some idea of the manysided treatment of which may be gained by naming the headings printed in larger type, as follows: Topography, formation of the soil, result of twenty years observation on the temperature, barometric observations, moisture and precipitation, clouds and sunshine, wind, wind and temperature, wind and clouds, vegetation, the prairies, water, swamp and moist localities, plants of cultivated land, pasture, waste land and roadside, introduced plants, cultivated plants, systematic review of the plants about Peoria and in the State of Illinois. This surely furnishes a deal of data for estimating the value of the various factors which have reacted to determine the presence of the plants of the district. Then comes the catalogue proper, covering forty pages, while the rest of the work is devoted to comparative statistics, and the geographical distribution of the genera and species. The name of each plant in the list is followed by (1) a sign showing if annual, biennial or perennial, (2) the habitat, (3) the abundance or rarity of the species, indicated on a scale of ten by Roman numerals, (4) the relative number of individuals in the proper habitat, indicated on a scale of ten by Arabic numerals, and (5) limits of the distribution in North America; and all this with few exceptions in a single line. At the end of each order is a list of additional plants of the immediate region round about, and of those occurring still further away toward the several points of the compass. The catalogue enumerates 809 species of indigenous vascular plants, and in addition thereto 68 mosses and 19 liverworts with the habitat of each, and a simple list of 36 lichens, 39 fungi, and about 10 algæ. Occasional lapses in proof reading occur, but the general typographical appearance is good. The thoroughness and attention to details merit emulation, although it may rarely be advisable to use so much space for meteorological matters. 


\section{$2 \mathrm{BHL}$ Biodiversity Heritage Library}

1883. "Editorial Notes." Botanical gazette 8(11), 340-343.

https://doi.org/10.1086/325739.

View This Item Online: https://www.biodiversitylibrary.org/item/27484

DOI: https://doi.org/10.1086/325739

Permalink: https://www.biodiversitylibrary.org/partpdf/221471

\section{Holding Institution}

New York Botanical Garden, LuEsther T. Mertz Library

\section{Sponsored by}

MSN

\section{Copyright \& Reuse}

Copyright Status: NOT_IN_COPYRIGHT

This document was created from content at the Biodiversity Heritage Library, the world's largest open access digital library for biodiversity literature and archives. Visit BHL at https://www.biodiversitylibrary.org. 